\title{
Border policy centre stage: three takes on the making, managing and understanding of borders
}

\author{
Sara Svensson ${ }^{1,2}$ \\ Published online: 23 June 2020 \\ (c) European Consortium for Political Research 2020
}

\section{Books reviewed:}

Debating and Defining borders: Philosophical and Theoretical Perspectives

Cooper, Anthony and Søren Tinning (London and New York, Routledge, 2020), 260 p. ISBN 9780815357179.

The Border: Policy and Politics in Europe and the United States

Schain, Martin A. (Oxford, Oxford University Press, 2019), 314 p. ISBN 0199938679.

\section{Boxing Pandora: Rethinking Borders, States, and Secession in a Democratic World \\ Waters, Timothy William (New Haven and London, Yale University Press, 2020), 320 p. ISBN 0300235895.}

During the emergence and spread of a new corona virus in late 2019 and early 2020 policymakers in a number of countries had few tools with which to fight it. "Closing borders" was one tool that national policymakers had access to and which many instinctively picked up. Even though it rarely meant full closure-goods and some people were allowed to cross national entry points on varying conditions - the crisis demonstrated the radical power and innate bluntness of national border policy in the twenty-first century. International coordination proved difficult as the World Health Organisation in vain argued against travel bans and closed borders. The European Union's inaptitude to make its member countries coordinate policies at internal and external borders is likely to have long-term ramifications on trust, politics and policy. Opening borders saw more coordination efforts, with, for instance, Association of South East Asian Nations (ASEAN) seeking to set up a common set of procedures in May 2020, but the actual level of coordination in this phase remains

Sara Svensson

Sara.Svensson@eui.eu

1 European University Institute, Fiesole, Italy

2 Halmstad University, Halmstad, Sweden 
to be seen. The crisis also highlighted the existence of borders within countries, as national and subnational policymakers experimented with restrictions of mobility that effectively created barriers to crossing internal boundaries.

The three books reviewed in this essay were written before the pandemic but provide relevant insights for what might-or also what should-come next when it comes to borders and especially border policy. While the authors and editors of the three books have different disciplinary origins (political science, law, political geography and philosophy, respectively), the books all relate to policy in distinct ways. The first provides a policy overview, the second is policy prescriptive and the third examines the fundamental concepts upon which (border) policy rests.

Schain starts with the salient point that "border governance has emerged as an important focus of policy in itself, rather than merely contingent on trade and, above all, on immigration policy" (Schain 2019: 1). The book pursues a classical aim in policy sciences, namely, to explain policy change and/or policy differences, either over time or across political domains. In this case, he does both in that he compares the policy and politics of borders in Europe and the USA. These two political systems are often compared in public debates, and within the borderland literature, one can find good examples of scholarship based on case studies (e.g. Blatter 2004), but Schain stands out in providing such an in-depth, thorough and consistently comparative approach. As many others, he comments on the peculiarity and paradox of borders that simultaneously become softer and harder. Still, he concludes that "what is striking about the evolution of policy is the increased priority given to border policy over time, along with the hardening of policies of border controls for the movement of people" (Schain 2019: 209). The analysis does not shy away from the human cost of these harsher policies, but at the same time does not dwell on this and instead makes the point that the effectiveness is questionable. One important line of argumentation throughout the book is the need to distinguish not only between the rhetoric of political leaders and what is actually happening on the ground-e.g. how successive rounds of leaders may vow to decrease new arrivals crossing the border, while the number of immigrants keep rising-but also between rules and their implementation. For instance, the increasing difficulty in crossing borders is due to changes in enforcement practices, both at the borders and within territories. Schain backs up his argumentation with a wealth of data, much of which must have been obtained through numerous interviews with officials scattered across the two continents. He concludes that the new centrality of border policy can be explained by political dynamics induced by perceptions of state weakness and/or perceived inability to protect national values of identity and legality. However, while the end result is similar, these political dynamics have played out differently on the two sides of the Atlantic, with, for instance, interest mediation by both the security-industrial network and citizen-driven NGOs playing more a central role for the policymaking process in the USA.

While Schain deals with multiple national policies that relate to or derive from existing national borders, Timothy William Waters provides a book-length argumentation for one single thesis: the world needs a new system for when to allow national borders to change. Written with the logical and stringent approach of a legal scholar, the book offers an analysis of the underlying assumptions and processes of first the 
current system and then his alternative proposal. The book's first part drives home the point that (too) many have come to take a particular normative view for granted, namely that the world should try to stay as close as possible to maintaining "current borders" or chaos will follow. What "current borders" actually mean is the borders of 1945 , since the new states that have emerged since then have generally kept colonial borders (in the context of decolonisation) or internal regional borders (in the case of dissolution of federal states such as the Soviet Union or Yugoslavia). In an apt metaphor, he calls for our compassion for "groups that didn't win a seat in the historical game of musical chairs that ended in 1945" (Waters 2020: 144). The first part of the book especially draws attention to how limited the so-called right to selfdetermination has become. This entails an interesting and partly provoking discussion on the status of minorities, where Waters advances the position that a minority is never a "people" in the current system. He also argues against the common view that the system of maintaining territorial integrity promotes stability and prevents violence. The second part of the book is devoted to the system that he would like to see instead. Outlining what he simply calls "the new rule", he argues for the use of referendums to allow self-defined communities to challenge states' territorial integrity. The only restrictive rules should be that these self-defined groups should have some minimum population (suggested at one million residents), some minimum contiguity of territory and that referendums crossing international frontiers should not be allowed. He acknowledges the many criticisms that have been raised against referendums (e.g. Vidmar 2019), but argues that the possibility of iterative plebiscites and cascades could be at least as good as the current systems in mitigating some dangers. Naming the book after the myth of Pandora, he reminds us that what was kept in her box after the evils had been let out was actually hope. Therefore, we should open the box and dare to embrace that hope.

Finally, Cooper and Tinning's (2020) edited volume lets border scholars, loosely defined, and philosophers, discuss the meaning of borders in the contemporary world. The book aims at rectifying what the editors see as two deficits in the borderland literature. It seeks to engage philosophers with the field of border and borderland studies, and to place borders at the centre of study, and not do it through other concepts, such as nationalism, sovereignty, citizenship or globalisation. This has resulted in a volume that on the one hand repeats conceptual discussions that are familiar to someone that has followed the border studies literature. This concerns especially the possible distinctions between the concepts of borders, boundaries, limits and frontiers, and their corresponding terms in other major Western languages such as German, French or Spanish. On the other hand, the inclusion of philosophers does lead to engagement with fresh metaphors, such as the threshold, the horizon and the contour. For instance, centre to Caterina Resta's chapter Walled borders: beyond the barriers of immunity of the nation-states is an image of a memorial on the Italian island of Lampedusa that is shaped in the form of a gate and dedicated to those who have died trying to enter Europe. Europe's external borders may be increasingly walled, but a border is also a gate or a door with a threshold that only some are able to step over. The volume also contains a beautiful reflection on the meaning of Kafka's Before the Law, written by the well-known border scholar and political geographer Henk van Houtum. In recounting Kafka's short story about a 
man waiting a whole life to be let in by the law only to be told at the end that there had been a gate for him but that it is now shut, van Houtum asks why we wait at the border and "b/order ourselves". Part of the answer is how we encounter professional border waiters in the form of border guarders and part is how to "wait before the law", to reproduce the law and to make the law powerful (van Houtum 2020: 186). At the same time, the question cannot be fully answered, since the border is also a question in itself.

Border studies is an inter- and intradisciplinary field of study comprising scholars from different disciplines. From the point of view of political science, it also covers various fields within the discipline, such as planning studies, policy studies and core political issues. The policy science subfield of political science is often said to comprise both the study of and the study for policy (cf. Bardach 2012; Dye 2016; Peters 2015), and together, these three books provide insights for both aspects. Some might pejoratively discharge conceptual analysis such as the one provided by Cooper and Tinning as too much of a semantic discussion, but at the heart of politics and policy are our understanding of the world through language, and it would indeed matter if policymakers and citizens would see the delimitations around their territories as horizons rather than walls. At the same time, a simultaneous reading of the three books makes visible how the interdisciplinary nature of border studies not only is a strength but also requires effort and willingness to understand (Newman 2005). A political scientist would need at least some acquaintance with the traditions of legal scholarship to appreciate why the author chooses a deliberately provocative style, and the same political scientist would need solid political theory training to be able to fully follow the content in the Cooper and Tinning volume. In fact, the latter contains some chapters that are so heavy with philosophy-specific terminology that they would be entirely inaccessible to a general policy audience.

In a chapter in the Cooper and Tinning volume on how River Grande became the border between the USA and Mexico, Edward Casey writes that "edges are an endemic feature of a world of discrete things and events" (Casey 2020: 70). At the same time, the conclusion to that volume brings home the "sheer messiness of borders" (Cooper and Tinning 2020: 251), something which became obvious in the wake of Covid-19 induced crisis in 2020. As a consequence, border policy is likely to increase in importance as a subject of scholarship. For those specialised or interested in the policy science subfield of political science, these books constitute a possible entry point to this field of study.

\section{References}

Bardach, E. 2012. A practical guide for policy analysis: The eightfold path to more effective problem solving, 4th ed. Los Angeles: Sage Publications.

Blatter, J. 2004. From 'spaces of place' to 'spaces of flows'? Territorial and functional governance in cross-border regions in Europe and North America. International Journal of Urban and Regional Research 28(3): 530-548. 
Casey, E. 2020. Outflanking the border wall at La Frontera. In Debating and defining borders: Philosophical and theoretical perspectives, ed. A. Cooper and S. Tinning, 70-82. London and New York: Routledge.

Cooper, A., and S. Tinning. 2020. Conclusion. In Debating and defining borders: Philosophical and theoretical perspectives, ed. A. Cooper, and S. Tinning, 251-257. London and New York: Routledge.

Dye, T.R. 2016. Understanding public policy, 15th ed. New York: Pearsons Education.

Newman, D. 2005. Borders and bordering. Towards in an interdisciplinary dialogue. European Journal of Social Theory 9(2): 171-186.

Peters, B.G. 2015. Advanced introduction to public policy. Cheltenham: Edward Elgar.

Van Houtum, H. 2020. The Janus-border of the Monad and the Nomad: An essay on the philosophy of b/ordering and othering. In Debating and defining borders: Philosophical and theoretical perspectives, ed. A. Cooper and S. Tinning, 181-194. London and New York: Routledge.

Vidmar, J. 2019. Secession and the limits of democratic decision-making. In Changing borders in Europe: Exploring the dynamics of integration, differentiation and self-determination in the European Union, ed. J. Jordana, M. Keating, A. Marx, and J. Wouters. New York: Routledge.

Publisher's Note Springer Nature remains neutral with regard to jurisdictional claims in published maps and institutional affiliations.

Sara Svensson is Jean Monnet Fellow at the European University Institute in Florence, Italy, and Senior Lecturer at Halmstad University, Sweden. Her research focuses on policy formation and governance structures in European cross-border regions. 